\title{
Skrifgebruik en Skrifgesag in die postmodernistiese konteks
}

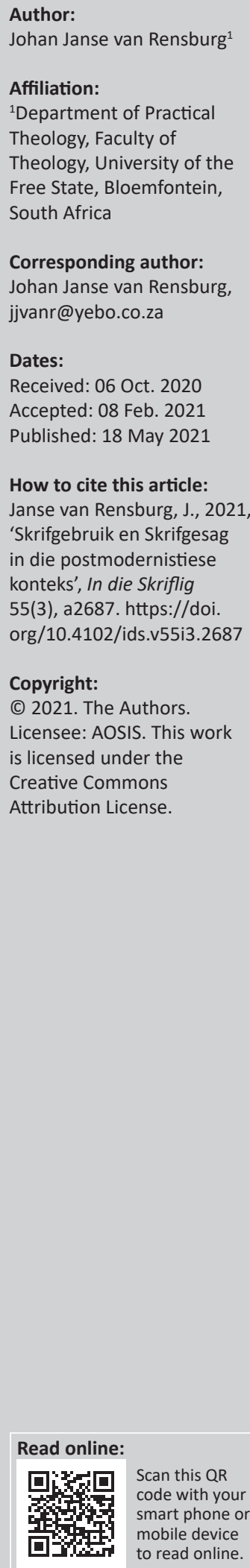

Scripture use and Scriptural authority in the postmodernist context. This article focused on the burning issue of the authority of Scripture and the way that it is currently used in the Christian and theological community. The research was necessitated by the gap between academic epistemology and the use of the Bible in religious activity. The research illustrated how a different understanding of the authority and interpretation of the Bible caused a clear division in church and society, particularly in the Reformed churches. The aim of the research was to illustrate the current abuse of the Bible in religious debate to legitimise preconceived convictions on theological and ethical issues. It was found that, even within the Reformed tradition, the opposing use of Scripture has caused diversity in the church community; thereby causing a serious break in the unity of the church. During the research process, it became clear that a radical new approach to Scriptural interpretation opposed the traditional Reformed understanding of the application of the Bible as per the three main confessions of the Reformed faith. What influenced such a radical new way of Scriptural authority? It was found that an analysis of philosophical systems, leading to the postmodern era, clearly prepared the way for an approach to search for the so-called true meaning of the text behind the text. This new approach was juxtaposed against the Reformed use of Scripture in the immanent text of the Bible and application thereof in the Reformed confession.

Contribution: All over the world and also in South Africa, the church community seems to be drawn into a battle for survival. Many church members have lost their faith, abandoned the church membership or moved on to other religions, mainly due to the way Scripture is currently viewed and applied. Unless the confusion in the understanding of the Bible is cleared, the process will deteriorate rapidly. In particular, the theological training of ministers and pastors needs careful consideration. Some academics have denounced their faith in the existence of God in favour of a post-theistic conviction. Students are taught that the Bible is not the Word of God, but human words about God. Such convictions have caused great confusion in church communities. It is envisioned that this research, published in a scientific journal, will underline the urgent need for the church, in general, and the Reformed faith, in particular, not to ignore the seriousness of the matter.

Keywords: authority of Scripture; postmodernodernism; hermeneutics; universalism; fundamentalism; biblisism; Reformed; confessions.

\section{Inleiding}

Postmodernisme het die konteks in Suid-Afrika en die wêreld fundamenteel verander. Die filosofiese struktuur van die postmodernisme het ook die Christelike geloof op nuwe en selfs ongekende wyses uitgedaag. Dekonstruksie het die vrymoedigheid en ruimte geskep om al hoe meer kritiese vrae oor die Skrif en teologie te vra. Die huiwering om twyfel oor die bestaan van God en die gesag van die Skrif uit te spreek uit vrees om deur die geïnstitusionaliseerde kerk gestraf te word, is selfs binne die kerk en teologie met vrymoedigheid vervang om spekulerend met nuwe strukture en konsepte oor God te eksperimenteer. Abel Pienaar (2010) verwelkom dit dat daar 'n nuwe openheid en vrymoedigheid gekom het om twyfel oor God uit te spreek.

\section{Probleemstelling}

Hermeneutiek as wetenskaplike dissipline word met die verantwoordelikheid getaak om die Bybel in die kontemporêre konteks in Suid-Afrika te interpreteer. Dit het egter nie net in ons land nie, maar wêreldwyd toenemend 'n enigmatiese verantwoordelikheid geword. Die eksegetiese 
landskap het sodanig verander dat daar 'n skeiding gekom het in die wyse waarop die Skrif verstaan en toegepas word. Die volgende probleemstelling kom aan die lig:

Die bekendstelling van die nuwe woord-vir-woord vertaling van die Bybel in 2020, skep die uitdruklike persepsie dat die Bybelgenootskap so na as moontlik aan die oorspronklike teks en bedoeling wil kom. In teenstelling hiermee is daar ' $n$ algemene tendens om van hierdie hermeneutiese beginsel weg te beweeg na 'n esoteriese verstaan van die teks.

Hierdie vrysinnige benadering toon duidelike ooreenkomste met die postmodernistiese filosofie van dekonstruksie en die veelheid van narratiewe. Is dit moontlik om 'n verband te lê tussen die huidige algemene gebruik van die Skrif en die filosofiese bedding van die postmodernisme?

Die huidige stand van Skrifgebruik, wat deur die vrysinnige hermeneutiek bevorder word, lei tot ongekende verdeeldheid in die gereformeerde teologie en in onderlinge kerklike verhoudings. Gemoedere loop hoog en dreigemente van dolering en skeuring laat die sekulêre samelewing regop sit terwyl duisende lidmate die gevestigde kerke verlaat omdat hulle nie meer die heftige en verwarrende stryd kan verduur nie.

\section{Hipoteses}

Die hermeneutiese probleme waarmee die Kerk gekonfronteer word, is nie nuut nie. Fundamentele veranderings het die diskoers egter tot by 'n gevaarlike breekpunt laat ontwikkel. Die liefde van baie vir die Woord skep die indruk dat alles wél is, terwyl die enorme meningsverskil oor die Woord onderspeel word.

Die gesag, gebruik en toepassing van die Skrif moet dringende aandag kry om lidmate in hulle geloofsbeoefening by te staan. Daar is tans ' $n$ enorme afstand tussen teologiese wetenskap en geloofpraktyk wat tot twyfel en selfs ongeloof aanleiding gee. Terwyl kritiese kommentaar oor die gesag van die Skrif die teologiese toneel oorheers, veroorsaak hierdie diskoers onsekerheid en selfs ongeloof by lidmate. Is die Bybel die Woord van God of is dit mensewoorde oor God? Moet die Skrifteks ernstig opgeneem word, of beteken dit iets anders as die immanente interpretasie? Voorbeelde van hierdie verwarring is die sogenaamde gay-tekste, die maagdelike ontvangenis van Jesus en die opstanding.

\section{Metodologie}

Die doel van hierdie navorsing is om die algemene Skrifgebruik in die huidige konteks in Suid-Afrika te evalueer. As sodanig word geen induktiewe kritiek of analise van standpunte gedoen nie, behalwe met enkele uitsonderings. Verder word aan die geskiedenis van die historiese en tekskritiek eweneens nie aandag gegee nie. Die navorsing moet kan aantoon op watter wyse die Skrif in die algemeen aangewend en/of misbruik word wanneer nie aan die bedoeling en konteks van die teks of die geheel van die
Skrif aandag gegee word nie. Die navorsing word juis daarmee bemoeilik, aangesien wetenskaplike literatuur op akademiese vlak 'n bydrae lewer, maar nie noodwendig die alledaagse gebruik reflekteer nie. Hoewel aanvaar word dat daar oorvloedige en entoesiastiese gelowige gebruik van die Skrif in eredienste, Bybelstudies en persoonlike stiltetye aanwysbaar is, word in hierdie navorsing slegs aan die opsigtelike misbruike aandag gegee. Die kernvraag is daarom: Hoe omvangryk is die postmodernistiese tendens om die gesag van die Skrif te relativeer?

\section{Filosofiese invloed}

Die worsteling met hermeneutiese vraagstukke het 'n lang aanloop. Die invloed van filosofiese denke op teologiese besinning is duidelik waarneembaar. Heyns (1967) se bespreking van Denkers deur die eeue toon duidelik hoe 'n nuwe beskouing oor waarheid en werklikheid, menslike wil en Christelike etiek 'n bybelse lewens- en wêreldbeskouing uitgedaag en vir verandering voorberei het. Die kontemporêre tendens om 'n dieper betekenis van die teks te soek, kan byvoorbeeld duidelik met Immanuel Kant (1724-1804) se ontleding van kennis en waarneming in verband gebring word. Die waarneming van die werklikheid word vir 'n verskuilde betekenis ingeruil. Kant sou sê dat die teks soos dit daar staan (das Ding aan zich) nie die ware betekenis openbaar nie. Dit is slegs ons ervaring wat ons analise van die werklikheid (wat ons sien, hoor en lees) beïnvloed. Daar is in sy benadering ' $n$ dieper en ware betekenis agter die werklikheid. Dit is betekenisvol dat Kant die klem op die rede vervang het met ' $n$ nuwe waardering vir die ervaring.

Die ervaring word bepalend in die ontleding van die werklikheid. In sy Kritiek van die praktiese rede vra Kant (1977) na die morele syn van die mens en kom tot die gevolgtrekking dat moraliteit nie in eksterne normering bestaan nie, maar in die innerlike wil. Goeie gedrag is nie wat die wêreld as goed beskou nie. Slegs die menslike wil is onvoorwaardelik goed. Vandaar die beginsel van 'n kategoriese imperatief. Die vraag is nie wat ek mag doen nie, maar ek moet ( $d u$ sollst) doen wat volgens my innerlike moraliteit goed is. Hierdie klemverskuiwing van 'n objektiewe na 'n subjektiewe vertrekpunt word in die filosofie met Copernicus se astronomiese ommekeer (die aarde beweeg om die son en nie omgekeerd nie) verbind. Die verband en ooreenkoms met Kant se moraliteit is opsigtelik. Daar is 'n sterker wordende tendens in die Skrifinterpretasie om nie met die immanente betekenis van die teks te volstaan nie, maar deur te dring na 'n meer subjektiewe aanpassing van die teks. In sy kritiek op die eksegetiese metode van C.J. Collins, kies Castle (2018:7) uitdruklik 'n immanente hantering van die teks: 'The mistake is to read the Bible in a way other than how it presents itself.' (p. 15). Die kerklike of teologiese hermeneutiek word vir 'n persoonlike of private interpretasie verruil. Die sogenaamde gay tekste word byvoorbeeld deur sommige teoloë en kerkleiers aangepas om besonderhede by die teks te voeg sodat dit hier om losbandige seks gaan en nie om selfdegeslag-verhoudings nie. Só het die Algemene Sinode 
van die Nederduitse Gereformeerde (NG) Kerk in 2015 besluit dat selfdegeslag-verhoudings nie teen God se wil is nie.

Wat hier relevant is, is die beginsel dat daar, volgens Kant (1977), 'n werklikheid agter die waarneming is. Die invloed van hierdie denke word treffend geillustreer deur 'n bekende skildery van René Magritte (1898-1967). 'n Tipiese Europese man word met 'n netjiese pak klere en 'n deftige pluiskeil in die skildery uitgebeeld, maar sy hele gesig is met ' $n$ groot groen appel bedek. Hoe lyk sy gesig? Wie is hy? Die kommentaar by die skildery lees: 'In this selfportret Magritte adresses themes central to much of his work - what lies beyond the visible? Can people ever comprehend what they see?' (GrahamDixon 2017:303). Toegepas op die hermeneutiek, word die immanente lees van die Skrif (soos dit daar staan) deur 'n dieper betekenis vervang. Die standpunt van Jonker (1976:33-34) dat die teks hanteer moet word soos dit daar staan, het duidelik in die slag gebly. Martin Heidegger (1889-1976) se eerlike worsteling met Skrif en teologie het eweneens die beginsel van kritiese analise bevat. Sy beginsel van dasein staan teenoor die tradisionele eskatologie van 'die eindtye' en worstel met die vraag na die kontekstuele bestaan. Die mens se individualiteit en eindigheid vereis 'n eerlike keuse om die rug op die kollektiewe wêreld en openbare normering (die kerk) te draai. Dit vereis 'n fenomenologiese reduksie wat afgestem is op erkenning van die eie bestaan (Dasein) (sien Wolfe 2014). Hierdie kritiese ingesteldheid, gemotiveer deur 'n eksistensiële fokus op die Dasein (Heidegger 1962), het gelei tot sy afskeid van die neo-Skolastiek en die geloofsbeginsels wat hy as kind by sy ouerhuis geleer het. Die ooreenkoms met die huidige diskoers oor selfdegeslag-verhoudings om die eie bestaansgeluk bo die gangbare kerklike Skrifverstaan te stel, is opsigtelik. Dit is besonder betekenisvol dat sy denke op 'n direkte wyse die filosofie van postmodernistiese denkers soos Derrida en Baudrillard beïnvloed het. Schrag (1985:24) is van mening dat Heidegger se kritiese lees van die teks 'n direkte invloed op Derrida se konsep van la diférance gehad het (vir Heidegger se invloed op die postmoderne denkers, sien Janse van Rensburg 2000:16-17, 24). Strauss (1998:13-33) meen dat elemente van sy filosofiese denke tot 'n konsep van postmodernistiese filosofie saamgevloei het.

Die paradigmaskuif van modernisme na postmodernisme is hoofsaaklike deur bogenoemde filosofiese stromings voorberei. Dit is egter 'n gekompliseerde gesprek, aangesien Flax (1990:188-189) daarop wys dat die omskrywing van postmodernisme nie uniform is nie. Loevlie (1992:88-105) stem saam dat ' $n$ gemeenskaplike definisie byna onmoontlik is. Tog is daar gemeenskaplike kenmerke waarmee postmodernisme geïdentifiseer word. Vir die bespreking oor die hermeneutiek van die Skrif is die volgende merkers belangrik:

- Die begrip narratief word gebruik as 'n korreksie van die konsep van vaste strukture. Postmodernisme is poststrukturalisties. Vaste sisteme en strukture is die resultaat van modernisme en word in 'n postmodernistiese benadering geïgnoreer of afgebreek. Die werklikheid word deur 'n verskeidenheid van narratiewe gefragmenteer. Toegepas op bybelse hermeneutiek, beteken dit dat een gestruktureerde metode van Skrifinterpretasie en een verstaan van die teks nie meer moontlik is nie.

- Die fragmentering van tekste word deur dekonstruksie bewerkstelling. Volgens Degenaar (1996:5-21) het Derrida se beginsel van dekonstruksie die Westerse idee van logosentrisme (eenheid van waarheid) laat implodeer (kyk ook Degenaar 2016). Bybelse hermeneutiek word hiervolgens 'n proses om nuwe verstaansmoontlikhede aan tekste te verleen. Die gevestigde betekenis wat in die verlede aan woorde en taal gegee is, word deur dekonstruksie verander om 'n konstante proses van verandering aan bestaande betekenis aan te dui. Volgens Seidman (1994:204-205) kan dekonstruksie beskryf word as verset teen enige vorm van gevestigde gesag. Is die huidige verwerping van bestaande teologiese hermeneutiese beginsels soos byvoorbeeld in die belydenisskrifte van gereformeerde kerke dwarsoor die hele wêreld, nie juis 'n bewys hiervan nie?

- Hermeneutiek word omvorm. In die postmodernistiese verstaan van die werklikheid is daar geen feite nie, maar slegs interpretasies. Heelan (1985) veronderstel interpretasie as die gebruik van persepsies. In kontemporêre hermeneutiek speel persepsies daarom 'n oorheersende rol en nie langer die interpretasie van feite in die teks nie.

- Veelheid van narratiewe beteken dat die beginsel van vasstaande en altyd geldende antwoorde verwerp word. Daar is nie meer een waarheid vir almal nie. Absolute waarheid word vir 'n veelheid van moontlikhede verruil. Jacques Derrida se la diférance impliseer dat die waarheid nie net anders is nie, maar altyd en aanhoudend verander.

- Die spreekwoordelike 'dood van die outeur' beteken dat dit nie meer nodig is om na die bedoeling van die outeur te vra nie. Die 'teks' word 'n metafoor vir die lewe, en die betekenis van die lewe moet telkens nuut geïnterpreteer word. In die huidige debat oor selfdegeslag-verhoudings word die argument byvoorbeeld gebruik dat Moses en Paulus se konteks anders was en dat die betrokke tekste daarom nuut geïnterpreteer moet word. Pippen (1991:161) wys daarop dat persoonlike omstandighede en betrokkenheid (subjektiwiteit) by Derrida se la diférance impliseer dat die teks en konteks elke keer verander. So word 'waarheid' tot 'my waarheid' omvorm.

- Die beginsel van la diférance funksioneer as die interdinamika van dekonstruksie. Die werklikheid is nie alleen anders as wat ons aanvaar of glo of dink nie, maar is konstant in 'n proses van verandering. Waarheid is nie, maar word aanhoudend anders. Sosiale en etiese sisteme kan daarom nooit 'klaar' wees nie en moet aanhoudend nuut gedefinieer word, net om weer aan 'n proses van verandering onderwerp te word.

- In die lig van voorafgaande is relativisme in 'n postmodernistiese verstaan van die teks onafwendbaar. Alhoewel ditontken word dat postmodernismenoodwendig tot relativisme lei, kan die deurvoer van filosofiese voorveronderstellings nie anders as om instrumente van 
relativisme te wees nie. Pieterse (2020:4-5) verwys in hierdie verband na die pogings van sommige navorsers om in die soeke na ' $n$ beter navorsingsmetodologie die relativisme in 'n postmoderne paradigma te omseil deur van postpostmodernisme te praat. Vir bybelse hermeneutiek beteken dit dat enige teks ' $n$ veelheid van moontlike interpretasies kan hê. Die huidige stand van Skrifgebruik toon sonder twyfel dat nie alleen denominasies oor die verstaan van die Skrif verskil nie, maar dat gelowiges binne een enkele (gereformeerde) geloofsgemeenskap soms heftig oor die Bybel verskil.

Omdat postmodernisme uiters moeilik verstaanbaar is en daarom selde deeglik bestudeer word, ontbreek die insig om te verstaan wat met menswetenskappe, teologie en ander dissiplines lank reeds aan die gebeur is. Die beginsel van hermeneutiek as interpretasie word al hoe meer in teologiese eksegese aangewend om vrysinnigheid in die betekenis van die teks te fasiliteer. In hierdie verband gee die gesamentlike publikasie van Scot McKnight en Grant Osborne 'n opsommende oorsig van resente navorsing oor Nuwe Testamentiese hermeneutiek (Mcknight \& Osborne 2004). Frederik Mulder (2020) toon met voorbeelde aan dat die kritiese hantering van die Skrif lank reeds in Europa en die res van die wêreld aan die gang is.

Die hewige reaksie op Rudolf Bultmann (1919-1985) se ontmitologiseringsteologie is eweneens nog vars in die geheue. Dit word allerweë aanvaar dat die invloed van sy Nuwe Testamentiese interpretasie steeds erken word (McKnight 2004:153-154). Sy vertrekpunt dat die Skrif mites bevat wat die verstaan van die teks verhinder, is met indrukwekkende metodologie gepostuleer (Bultmann 2007). Die Skrif moet van die mites gestroop word om die ware boodskap te ontvang. Hier is die kern van 'n esoteriese verstaan van die Skrif reeds duidelik sigbaar. Bultmann se verklaring van Christus se opstanding is ' $n$ sprekende voorbeeld. Christus het nie histories (werklik) opgestaan nie, maar die dissipels het die bedoeling van die vertelling verstaan dat Hy in hulle harte en bestaan moet opstaan. Bultmann se teologie het in die Suid-Afrikaanse konteks entoesiastiese ondersteuning van die gerekende teoloog, Ferdinand Deist, ontvang. Die metaforiese verstaan van die opstanding het ook 'n neerslag gevind in die teologie van die sogenaamde Nuwe Hervormers en ander protagoniste van 'n ontmitologiseringsteologie. Müller (2006) se verwerping van 'n historiese opstanding van Christus en 'n teïstiese godsbegrip (Müller 2010) is hiervan 'n sprekende voorbeeld. 'n Indrukwekkende lys van teoloë wat die immanente verstaan van die Skrif uitgedaag het, het momentum aan die vorming van 'n nuwe benadering tot Skrifinterpretasie gegee. Feitlik deurgaans het postmodernistiese filosofie 'n invloed op dié vrysinnigheid gehad. Die opmerking van Scot McKnight (2004:150-151) in hierdie verband is betekenisvol: 'It is not possible here to point to the manifold ways in which Jesus has been captured by moderns for their own agendas.' Dit is dus 'n valse indruk wat geskep word dat wetenskaplike kritiek teen die Skrif ' $n$ eenparige en oortuigende front vorm wat twyfel in die openbaringskarakter van die Skrif regverdig. Hoewel verwag kon word dat die historiese kritiek die voorwetenskaplike lees van die Bybel onmoontlik sou maak, is Ferguson (2013:13-17) van mening dat die wyer invloed van die historiese kritiek op die geloofsgemeenskap twyfelagtig is. Nogtans is dit noodsaaklik dat die Skrif in die algemeen en die Christologie, in besonder, in die lig van die historiese kritiek bestudeer sal word indien die Bybel se sentrale plek in die geloofsgemeenskap gehandhaaf en uitgebrei sal word (Fergusson 2013:129).

\section{Invloed van filosofiese denke op die Skrifgebruik}

Die invloed van filosofiese stromings op teologiese denke kan moeilik oorskat word. Die verabsolutering van die rede was die begin van die magtige stroming van die modernisme. Die wetenskapsideaal het ongebreidelde mag aan wetenskaplike navorsing verleen. Hierdie invloed is om begryplike redes in teologiese opleiding ingelyf. Die traumatiese effek wat die historiese en tekskritiek op teologiese studente gehad het, word uitvoerig deur Mulder (2011) in sy boek Opgestaan uiteengesit. Met spesifieke en gedokumenteerde inligting toon hy an hoe die mitologisering van die opstanding van Christus tot ontgogeling, 'n geloofstryd en uiteindelike ongeloof by talle studente aanleiding gegee het.

'n Verdere invloed op die Skrifbeskouing in Suid-Afrika was die geweldige impak wat die Emerging Church (EC) op die wêreldtoneel gehad het. Blootstelling aan die Skrifbeskouing en leerstellings van die EC het daartoe gelei dat studente en predikante al hoe meer 'n interpretasie van die teks aanvaar het wat van die tradisionele hermeneutiek afgewyk het. Leonard Sweet se Quantum spirituality (1991) het 'n ongekende oplewing van belangstelling in spiritualiteit tot gevolg gehad. Die publikasies van invloedryke Suid-Afrikaanse teoloë, byvoorbeeld Niemandt (2012) en Joubert (2009), wat die EC se teologie opgehemel het, het daartoe gelei dat al hoe meer ontluikende gemeentes in gereformeerde en Pentakostalistiese kerke gestig is.

Die invloed van Bultmann se ontmitologiseringsteologie word op 'n illustratiewe wyse by die EC aangetref (vir 'n volledige uiteensetting van die ontluikende kerk, sien Janse van Rensburg 2011). Volgens Fosdick (1878-1969) is die leer oor Jesus se versoeningsdood waarin Jesus as plaasvervanger in ons plek vir ons sondes geboet het, 'n barbaarse gedagte. Vir Fosdick is Jesus se dood aan die kruis slegs 'n illustrasie van sy dienskneggestalte. Hy noem die idee dat Christus vir ons sondes gesterf het, 'n teologiese skande en 'n gewelddadige en bloedige godsdiens. Fosdick se gedagtes herleef in die werk van die Episkopaalse priester, Alan Jones. Hy het in sy boek Reimagining Christianity verklaar dat God nooit bedoel het dat Jesus se kruisdood as 'n versoening vir ons sondes beskou moet word nie. Daarom moet die kerk se fiksasie op die kruis gestaak word. Die God van wraak en die kultus van lyding wat volgens Jones 
$(2005: 132,168)$ ten grondslag van die kruisteologie lê, is nie langer aanvaarbaar in 'n postmodernistiese tyd nie. Die betekenis van die kruis moet dus herinterpreteer word sodat die kruis nie meer in die sentrum van die evangelie staan nie.

Hierdie radikale denke is deur die wêreldbekende skrywer van die EC, Brian McLaren, oorgeneem. Hy het immers erken dat hy deur Jones se denke beïnvloed is. In sy boek The secret message of Jesus (McLaren 2006) verduidelik McLaren dat Jesus anders beskou moet word as wat die kerk tot dusver gedoen het. Ons moet Jesus losmaak van die idee dat Hy gekom het om ons van ons sondes te verlos. In plaas van Jesus as 'n persoonlike Verlosser te sien, moet ons Jesus as 'n sosiale hervormer ontdek. Al was dit nie sy bedoeling nie, het Nelus Niemandt aan hierdie gedagte vleuels gegee met die stelling: 'Vir Jesus van Nasaret is die waarheid nie 'n klomp leerstellings nie. Waarheid is te vinde in verhoudings'. (Niemandt 2012).

In 'n poging om die missionale boodskap te bevorder, is die kerk daarvan beskuldig dat daar in die verlede 'n obsessie met dogmas was en dat die versorging van die armes as gevolg daarvan agterweë gebly het. Dit is eenvoudig onwaar. Dink maar aan Abraham Kuyper wat in sy Anti-revolusionêre Party daarop aangedring het dat dit ' $n$ halwe evangelie sou wees as die kerk slegs op verlossing sou konsentreer en die versorging van die armes sou verwaarloos (Janse van Rensburg 1979:67-74).

Dit het reeds duidelik geblyk dat die kruisevangelie in die EC ontmitologiseer word. Rob Bell (2011) volg die ontmitologiseringsgedagte verder as hy beweer dat die liefde die enigste blywende beginsel is. Daar is geen sonde of oordeel om mee rekening te hou nie.

\section{Openbaringsteologie teenoor 'n natuurlike teologie}

Artikel 1 van die NG Kerk se Kerkorde verklaar onomwonde dat die kerk op die onfeilbare Woord van God en die belydenisskrifte gegrond is. Hierdie vertrekpunt is waarskynlik as gevolg van die internasionale diskoers onder druk geplaas. Wolterstorff se standpunt dat die hele Bybel die Woord van God is, word deur Wisse (2002:159-173) verwerp. In Suid-Afrika is die pynlikste voorbeeld die geweldige stryd vir en teen apartheid (Strauss 2018:5-8). Dit kan met stelligheid beweer word dat die NG Kerk (en ander) aanvanklik nie wou aanvaar dat apartheid met die Skrif teenstrydig is nie. Op die keper beskou, was hierdie beleid egter dievrug van'nnatuurlike teologiewat'ngekompliseerde samelewingsorde tot God se wil omvorm het. Die uiteindelike besluit van die Algemene Sinodes van 1986 en 1990 het egter hierdie natuurlike teologie verwerp en na 'n Openbaringsteologie teruggekeer. In 'n insiggewende artikel ondersoek Speckman (2016:1-9) die onderdrukking van Skriftekste se betekenis ten einde op die klank af interpretasies te gebruik om politieke ideologieë gedienstig te wees. 'n Verdere voorbeeld van natuurlike teologie is die Algemene Sinode van die NG Kerk se besluit om die beginsel van diversiteit as amptelike beleid te aanvaar. Dit het beteken dat lidmate en teoloë wat op grond van natuurwetenskaplike en hermeneutiese oortuigings afwykende beskouings oor Skrifverstaan het, toegelaat word om 'n eie mening daarop na te hou. Hierdie verwikkeling is in ooreenstemming met die postmodernistiese beginsel van 'n veelheid van narratiewe en die sogenaamde collapse of unity. Daarmee is leertug finaal uit die NG Kerk geweer, terwyl die Nederlandse Geloofsbelydenis, artikel 29 die kerklike tug as een van die kenmerke van 'n ware kerk aanwys.

Nog 'n voorbeeld van 'n natuurlike teologie teenoor 'n openbaringsteologie word in die huidige diskoers oor selfdegeslag-verhoudings gevind. Die sogenaamde gay tekste (Lev 18-20; Rom 1 en 1 Kor 6) het in 'n Openbaringsteologie onteenseglike morele krag: 'Daar staan geskrywe'; 'God het gesê'. Die werklikheid is egter anders. Daar het nie alleen vrymoedigheid ontwikkel om die Skrif te weerspreek nie, maar daar het ook groter wordende vrymoedigheid ontstaan om uit die spreekwoordelike kassie te klim. Dit is asof die selfdegeslagidentiteit in die openbaar toegeneem het en via die openbare pers al hoe groter steun ontvang het. Die diskoers het al hoe meer gesteun op die feit dat seksualiteit 'n natuurlike en Godgegewe gawe is en dat die gay tekste nie oor verhoudings gaan nie. Hierdie teenstellende vertrekpunt is reeds verby 'n broederlike diskoers en het via verskeie algemene en streeksinodes tot hewige debatte en konflikterende emosies gelei.

Die vraag na die werklike bestaan van die Bose en gepaardgaande okkultiese verskynsels is in kerklike geledere eweneens met natuurlike skeptisisme beoordeel. Die woord okkult verwys na die bonatuurlike geheimenis van verskynsels. Aanvanklik het die parapsigologie verskeie okkultiese verskynsels wetenskaplik ondersoek. Talle publikasies van outeurs wat eerstehands met die okkulte te doen gehad het, het die lig gesien (Ouweneel 1978; Janse van Rensburg 1999). Die Algemene Sinode van die NG Kerk het egter die besluit oor die bestaan van die duiwel aan lidmate oorgelaat en die wenslikheid van 'n bediening aan okkulties geteisterdes afgewys. Daarmee is alle Bybeltekste wat na Satan, bose magte en okkultiese verskynsels verwys, met 'n skouerophaling geïgnoreer. Die bose is dan slegs die kwaad wat in elke mens is. Kwalitatiewe navorsing (Janse van Rensburg 2010:688) het egter bevind dat persone wat op een of ander wyse met okkultisme te doen gehad het, die verwysings na die Bose in die Skrif betekenisvol gevind het.

In sy kritiek op C.J. Collins se eksegetiese metode, kies Castle (2018:11-12) doelbewus om die Skrifverstaan in 'n openbaringsteologie te fundeer. Die proses van sekularisasie wat in 'n natuurlike teologie verraai word, was reeds in 1975 waarneembaar toe Ernst Wolf (1975:318) geskryf het: 'Der Weg von einer Ethik der ordnungen zu 
einer Ethik der Wandlungen bedeutet den tiefsten Einbruch in den konservativen Hang der bisherigen abandländischchristlichen Tradition'.

\section{Die Skrif as samebindende of verdelende faktor?}

Volgens die gereformeerde teologie is die Bybel die Woord van God, maar in 2020 verklaar die taakspan van die NG Kerk se verslag oor selfdegeslag-verhoudings dat dit nie beteken dat die mens se denkvermoë opgeoffer hoef te word nie (Algemene Sinode 2019). Die Kommissie (Algemene Sinode 2019) skryf:

Bybelinterpretasie is noodsaaklik en belangrik. Ons moet as geloofsgemeenskap saam onder leiding van die Heilige Gees soek na die betekenis van God se Woord. Bowenal: Ons verstaan die Bybel vanuit die hart daarvan, naamlik die evangelie van Jesus Christus. Hierdie verstaan van die gesag en interpretasie van die Skrif het die invloed gehad dat daar weer met vrymoedigheid na tekste gekyk kon word om nuut te vra na die betekenis daarvan. (n.p.)

Dit is waar dat die hermeneutiek ' $n$ kritiese funksie het, maar in hierdie aanhaling lyk dit te veel of die menslike denkvermoë in die hermeneutiek geprioritiseer word. Wanneer die menslike denkvermoë en menswetenskaplike inligting gebruik word om die bedoeling van die teks te verander, word onrus in die verstaan van die teks veroorsaak ( $\operatorname{sien} 2$ Pet 1:2021). 'n Sprekende voorbeeld wat die hermeneutiese toneel tans oorheers, is die invloed van die sielkunde in die herinterpretasie van die sogenaamde 'gay tekste'. In 'n voorlopige verslag van die Algemene Sinodale Moderamen van die NG Kerk wat in Maart 2020 sou dien, vra die opstellers:

Wat leer ons uit psigiatriese en sielkundige navorsing? Die indeks vir die beskrywing van psigiatriese afwykings [DSM] het immers homoseksualiteit uit hulle lys van psigiese afwykende gedragsverskynsels verwyder. Is homoseksualiteit aangebore of aangeleer? Wat leer ons uit Bybelnavorsing? Praat die Bybeltekste oor promiskue gedrag, of ook oor homoseksuele mense wat in 'n permanente verhouding van liefde en trou staan? (Algemene Sinode 2019:n.p.)

Nie 'n eksegetiese ondersoek nie. maar'n sielkundige verslag en 'n vooropgestelde hermeneutiese vertrekpunt (gay tekste handel nie oor verhoudings nie), word as raadpleging van die Skrif voorgehou. In 'n wetenskaplike artikel poog De Bruijne (2016) selfs om aan te toon dat die LGBTQ+ beweging eintlik net 'n uitbreiding van die Christelike seksuele etiek is en nie ' $n$ afwyking daarvan nie (De Bruijne 2016). Waar die Skrif vroeër as die eenheidsband gefunksioneer het, het dit nou tot diversiteit en vervreemding gelei. Die afskeid van 'n Openbaringsteologie is so radikaal dat 'n gerekende teoloog soos König (2009) verklaar dat die evangelie op die spel is.

Die wyse waarop hierdie konflik tans benader word, gaan die kerk nie nader aan 'n oplossing bring nie. Om die beswaardes se worsteling as kinderagtig of liefdeloos te bestempel, is kwalik die regte houding vir 'n oop gesprek
(Cilliers 2020). Louw (2020) formuleer die gevoel van baie beswaardes. Hy meen dat die gesprek so vasgeloop het dat ons te doen het met ' $n$ kerk waar hartlike broederskap onmoontlik geword het. Die verslag van die taakspan van die NG Kerk (2.2) wil egter nie van vasgelooptheid praat nie, maar verkies die begrip verstrengeling. Verstrengeling, meen hulle, kan ontknoop word. Die vraag is: Kan dit? Derrida se uitspraak in hierdie verband is nogal betekenisvol. Die beginsel van la diférance impliseer dat die subjek sowel as die teks meteens samebindend en verdelend inwerk op die werklikheid. Ulmer (1983:31) beskryf hierdie proses as 'the hinge that joins and seperates at once'. Dit is onafwendbaar dat 'n postmodernistiese hermeneutiek vanweë die relativerende element daarvan tot verdeling en skeiding aanleiding sal gee. Nelis Janse van Rensburg, voorsitter van die Algemene Sinodale Moderamen, het juis in 'n Sondag-radiogesprek verklaar: 'Ons gaan mekaar nie oortuig nie.'

\section{Voorbeelde van verkeerde of twyfelagtige Skrifgebruik}

Enkele probleme en vraagstukke in verband met 'n nuwe hermeneutiek is tot dusver kursories bespreek. In hierdie afdeling word 'n poging aangewend om enkele voorbeelde van 'n problematiese Skrifbeskouing en -gebruik aan aan te dui.

\section{Die eenheid van die Bybel}

Onder talle gelowiges word die Ou Testament as afgehandel en irrelevant beskou. Vanweë die skokkende verhale in die Ou Testament en morele wette wat vir die postmodernistiese mens onaanvaarbaar is, word die klem op die Nuwe Testament en Christus se verlossing geplaas. Hiervolgens is die God van die Ou Testament 'wreed' terwyl die God van die Nuwe Testament genadig en vergewensgesind is. Die Nederlandse Geloofsbelydenis (art. 3-5) het die eenheid van die kanonieke boeke uitdruklik beskryf. Dit beteken dat enige verabsolutering van die een Testament bo die ander as 'n vergryp teen die Woord van God beskou moet word. Die oplossing is daarin geleë dat 'n brug gesoek moet word om die oorgang van die Ou na die Nuwe Testament op 'n verantwoordelike wyse te bewerkstellig. Die verbond is uitnemend geskik om as hierdie brug te funksioneer (Janse van Rensburg 2012:25-26). In Castle (2018:13) se hantering van die daaglikse verslag van die skeppingsverhaal, plaas hy die openbaringsgebeure van die skepping binne die konteks van verbond. Greidanus (1999:25-29) het die eenheid van die Skrif as ononderhandelbaar beskou (vgl. ook artikel 4 en 5 van die Nederlandse Geloofsbelydenis). Greidanus se uiteensetting korrespondeer met die heilshistoriese grondmotief vir Skrifverstaan. God was met Israel op pad na die vervulling van die verbondsbeloftes in Jesus Christus.

\section{Nuwe Testamentiese aanhalings uit die Ou Testament}

Dit is algemeen bekend dat die Nuwe Testament se aanhalings uit en interpretasie van die Ou Testament deur sommige Ou Testamentiese wetenskaplikes verwerp word. 
Filippus se Christologiese interpretasie van Jesaja 53 is 'n sprekende voorbeeld. Hierdie gesprek is lank reeds aan die gang sonder om gelowiges en wetenskaplikes tot 'n vergelyk te bring. Sonder om die debat hier te voer, is dit voldoende om daarop te wys dat Filippus volgens Handelinge 8 deur die Heilige Gees gestuur is om die hofdienaar van Etiopië te ontmoet. Beteken dit dat verset teen die interpretasie van Jesaja 53 in Handelinge 8 ook 'n verset teen die Heilige Gees is?

\section{Algemene vergrype teen die Skrif}

\section{Biblisisme}

'n Sprekende voorbeeld van biblisisme is die redenasie wat ' $n$ dominee tydens 'n Algemene Sinode-debat oor selfdegeslagverhoudings gebruik het. Die spreker verwys na 1 Samuel 18:3 en suggereer dan dat Dawid vir Jonathan liefgehad het - 'liewer as 'n vrou'. Dit word aangebied as bybelse regverdiging vir selfdegeslag-verhoudings. In hierdie betrokke teksvers staan daar egter dat Dawid vir Jonatan liefgehad het 'soos homself'. 'n Ander vertaling sê 'soos sy eie siel'. Dit is nie duidelik waar hierdie spreker se afleiding oor 'n selfdegeslag-verhouding tussen Dawid en Jonatan vandaan kom nie, maar die onbesonne redenasie laat die vraag ontstaan: Was Dawid dan biseksueel, aangesien hy ook met Batseba 'n buite-egtelike verhouding gehad het? Verder: Regverdig die beweerde gay verhouding van Dawid en Jonatan dan ook alle gay verhoudings? Is Dawid se buiteegtelike verhouding met Batseba dan ook 'n regverdiging vir egbreuk? Dit is tragies dat 'n ander spreker hierdie betoog aangeprys het as die beste bydrae in die debat!

Nog 'n voorbeeld van biblisisme word in die hantering van Matteus 20:22 gevind. Jesus vra die dissipels of hulle met dieselfde doop gedoop kan word waarmee Hy gedoop gaan word. Uit die konteks is dit duidelik dat Christus van die lyding praat wat vir Hom voorhande was. Wederdopers gebruik egter hierdie vers om mense te oortuig dat hulle met dieselfde doop as Jesus (indompeling) gedoop moet word. Uit die twee voorbeelde kan ons aflei dat biblisisme die benadering is om 'n teks uit konteks te neem en letterlik te interpreteer sonder om die historiese, eksegetiese en hermeneutiese kontekste te verreken.

\section{Fundamentalisme}

Wat is fundamentalisme? Die wyse waarop die term in gesprekke gebruik word, bewys dat daar meer as een verstaan van die begrip is. In die algemeen wil die gebruiker sê dat die standpunt waarmee nie saamgestem word nie, onbuigsaam en onveranderlik is. Wat die Skrif betref, word mense van fundamentalisme beskuldig wanneer hulle daarop aandring dat die Bybel so sê. 'Daar staan geskrywe' was van Jesus se dae af die verwysing (Luk 4:8). Jy mag nie met die Bybel verskil nie. As jy onwrikbaar op die woorde in die teks aandring, is jy hiervolgens 'n fundamentalis.

Die oorsprong van die verset teen 'n fundamentele benadering tot die teks moet by die postmodernisme gesoek word. Die postmodernis, Lyotard (1984), het fundamentalisme geïdentifiseer as die uitsluitlike rede vir die onvermoë of onwilligheid om die spel van interpretasie te speel. Fundamentalisme word beskryf as die begeerte om mag oor ander uit te oefen. Sodoende verhinder fundamentalisme die vermoë van mense om aan die spel van interpretasie deel te neem en hulle eie narratiewe te ontdek. Duidelik is die motivering vir die aanval op fundamentalisme die postmodernistiese beskerming van die beginsel van 'n veelheid van narratiewe en die verwerping van een absolute waarheid (Lyotard 1984:206-208).

\section{Skrifuitsprake word gerelativeer}

Die Skrif was nog altyd die normering vir geloofs en kerklike lewe. Die moderne samelewing het klaarblyklik aanpassings en korrektiewe genoodsaak. 'n Sprekende voorbeeld is Paulus se voorwaarde vir die gebruik van die nagmaal. By die gebruik van brood en wyn moet die liggaam van Christus onderskei word (1 Kor 11:28-29). Reeds van die vroegste tyd af het die kerk se vroomheid in formele korporatiewe godsdiens uitdrukking gevind. Die erediens het, volgens Nauta (1963), uit twee dele bestaan. In die eerste deel van die diens waartydens die evangelie verkondig is, is almal toegelaat. Die geleentheid is gebruik om mense tot bekering en die aanneem van Jesus Christus as Verlosser op te roep. Die tweede deel van die diens was egter geslote vir nie-gelowiges. Slegs dié wat na belydenis van geloof gedoop is, is tot die nagmaal toegelaat.

Martoia (2007:109) meen egter dat hierdie manier van aanbidding nie in die Bybel teruggevind word nie. Dit is een van die eerste drumpels wat kerkleiers moet oorsteek om nuut oor aanbidding te dink, skryf hy. In talle gemeente word hierdie sogenaamde liturgiese gasvryheid in diens geneem. Inderdaad het die EC die formele karakter van aanbidding verander en verskraal tot informele byeenkomste waar die Woordverkondiging dikwels vervang is met narratiewe van mense se nood en haglike omstandighede, terwyl die nagmaal aan almal wat aanwesig is, bedien is. Mense moet in hierdie benadering eers toegelaat word om te behoort (aan die nagmaal deel te neem) en dan begelei word om te glo. In sy boek Nuwe drome vir nuwe werklikhede verwys Nelus Niemandt $(2007: 93,96)$ na die EC se beskouing dat alle mense as preChristene beskou en hanteer moet word. Duidelik word die Skrif nie toegelaat om normatief vir die nagmaal te wees nie.

\section{Christologie}

'n Heilshistoriese hermeneutiek interpreteer die Skrif in die lig van die Messiaanse voorspellings in die Ou Testament en die vervulling van die verbondsbeloftes in Jesus Christus (Castle 2018:15). Hoewel Christus in 'n postmodernistiese hermeneutiek nog aandag geniet, is die wyse waarop Christologiese Skrifverwysings hanteer word, radikaal uiteenlopend. Die negatiewe afwykings en waardebepalings ten opsigte van Christus se Persoon en lewe kan in 'n paar kategorieë verdeel word. 
Christus se ontvangenis en geboorte uit die maagd Maria word ontken. Josef word dan as biologiese vader van Jesus gesien. Andries Van Aarde (2001) se publikasie het verder gegaan om Christus se geboorte in die konteks van seksuele losbandigheid te plaas.

Kontemporêre besinning oor die persoon en werk van Christus sentreer op die ontkenning van Christus as die enigste weg tot verlossing. Die postmodernistiese filosofie, die New Age as vertoonvenster van postmodernisme en die EC het ' $n$ belangrike rol gespeel om die gelykheid van alle godsdienste te bevorder. Alle godsdienste verskaf in hierdie gewilde teologie 'n weg tot verlossing. Desmond Tutu (2011) skryf in sy boek God is not a Christian dat verskillende godsdienste net die verskeidenheid van kulturele verskille reflekteer en dat almal geloofsgenote is.

Die New Age het die wêreldmening geswaai met populêre liedere soos 'The World in Union' (temalied vir die rugbywêreldbeker elke vier jaar); 'One God', 'n pragtige lied waarin alle gelowe as aanbidding van dieselfde God besing word; en John Lennon se 'Imagine' waarin hemel en hel ontken word en algehele vrede sal heers. Al hierdie beskouings word onder die oorkoepelende begrip van universalisme saamgevoeg. Die verkeerde interpretasie van die Persoon en werk van Christus verteenwoordig die grootste misbruik van dieSkrif, aangesien dieSkrifverwysings oor Jesus se unieke verlossing oorvloedig en duidelik is (Joh 1:12; 3:16; Hand 4:12; 1 Joh 5:12; Heb 2:2-3; 4:1-11, om maar net 'n paar Skrifgedeeltes te noem).

\section{Postmodernistiese etiek teenoor Christelike etiek}

In Openbaringsteologie word die Christelike etiek in die eksplisiete en implisiete betekenis van die Dekaloog gefundeer, terwyl die uitlê en toepassing daarvan dwarsdeur die Skrif in historiese, digterlike, profetiese en evangeliese literatuur uiteengesit word. Baie is die mening toegedaan dat postmodernisme sonder enige etiese normering funksioneer. Dit is egter nie korrek nie. Terwyl die Christelike etiek korporatief en gemeenskaplik is, is postmodernistiese etiek onvoorwaardelik individualisties. Derrida se invloed is duidelik sigbaar. Die beginsel van die veelheid van narratiewe en die fokus op die individu se omstandighede en behoeftes, beteken dat die etiese hantering van die lewe nie in vasgestelde en geformuleerde skriftelikheid bestaan nie, maar volledig in elke mens se eie besluitneming geleë is. Talle Christen-gelowiges besluit selfs dat dit nie meer moontlik is om in 'n postmodernistiese tyd die etiese riglyne van die Skrif te gehoorsaam en toe te pas nie. Die implikasies hiervan is vir die kerk verreikend. Allereers beteken dit dat al die Skrifuitsprake oor seksuele losbandigheid eenvoudig geïgnoreer word. Daarmee word die omvattende bespreking van die Dekaloog in die Heidelbergse Kategismus (Sondag 34-44) verwerp.

\section{Kwasi-intellektuele argumente}

Daar is talle voorbeelde van pogings om van gewaande wetenskaplike inligting gebruik te maak om geloofwaardigheid aan kritiek teen die Bybel te opper. Die gevolg is dat twyfel gesaai word oor die betroubaarheid van die Bybel. Een so 'n voorbeeld is die artikel van Marius Krige, 'n heftige en gereelde kritikus van die Bybel. Krige (2010) skryf:

Sommige Ou Testamentiese skrywers was goed vertroud met die term Midrash, wat in kort neerkom op die afstof en herskryf van selfs eeue oue geskrifte om ' $n$ nuwe betekenis daaraan te gee en so ' $n$ nuwe bedeling daar te stel.

Dan gaan Krige voort deur na Romeine 16:26 te verwys en te beweer dat Paulus deur hierdie verwerkte geskrifte na die $\mathrm{Ou}$ Testament gekyk het en na aanleiding daarvan die profesieë van Jesaja verkeerdelik herinterpreteer het. Dit bring hom tot die gevolgtrekking dat die Messiaanse profesieë nie waar is nie. Die opsigtelike foute in hierdie argument skrei ten hemel. Midrash verteenwoordig beslis nie 'n praktyk om ou geskrifte te verander of te herskryf nie. Dit was 'n hermeneutiese oefening om die betekenis van die Talmoed te ondersoek en te interpreteer. Die uitgangspunt was deurgaans om die geopenbaarde en onaantasbare aard van die heilige geskrifte te erken en te bewaar.

\section{Natuurwetenskap en Skrif}

Natuurwetenskaplike kennis word ingespan om die onbetroubaarheid van die Skrif te bewys. So word beweer dat die Bybel se wêreldbeeld teenstrydig met die wetenskaplike feite is. Die argument lei dat die Skrif 'n aarde voorstel wat plat is en op pilare rus, na aanleiding van tekste soos 1 Samuel 2:8, Psalm 75:4 en Job 9:6. Die beredenering word uitgebrei deur te verwys na die RoomsKatolieke Kerk se weiering om Copernicus se ontdekking dat die aarde om die son draai en nie omgekeerd nie - te aanvaar. Dit lei tot die gevolgtrekking dat Skrif en wetenskap onversoenbaar is. Die Skrif gebruik die metafoor van pilare om vastigheid en bestendigheid uit te beeld. In die konteks van die tekste verwys dit na die sorg en voorsorg van God in tye van stryd en bedreiging. Dit is 'n foutiewe aanname om te glo dat outeurs van hierdie tekste werklik bedoel het om te sê dat die aarde plat is. Daarbenewens moet onthou word dat die Skrif ook verwys na sterrekundiges wat die ruimte bestudeer en selfs die Bethlehem-ster gevolg het. Sou hulle werklik in 'n plat aarde geglo het? Dit word beklemtoon dat die Bybel nie as 'n wetenskaplike handboek beskou en beoordeel moet word nie.

\section{Verandering van die bedoeling van die teks}

Die verandering van 'n missionêre benadering na 'n missionale benadering het impliseer dat die klem van verkondiging na dienslewering verskuif is. Wanneer mense dan vra waarom julle hierdie goeie werk doen, kan die evangelie verkondig word. Dit is heeltemal aanvaarbaar as 'n alternatiewe manier om sendingwerk te doen. Wanneer die bedoeling van 'n teks egter aangepas word om hierdie benadering te sanksioneer, is dit niks anders as 'n versteuring van die bedoeling van die teks nie. Petrus skryf dat ons altyd bereid moet wees om met sagmoedigheid en 
vrees verantwoording te doen aan elkeen wat van ons rekenskap eis omtrent die hoop wat in ons is (1 Pet 3:15). Die bedoeling kan egter nie wees dat ons oor die evangelie moet swyg totdat ons daaroor uitgevra word nie. Die voorafgaande gedeelte van die teks herinner ons juis dat daar in ons harte net heilige eerbied vir Christus moet wees. Daarom moet ons (en kan ons) altyd gereed wees om 'n antwoord te gee omtrent die hoop wat in ons is. Die klem val ook op die woord verduideliking wat dui op die vraesteller se behoefte om meer te weet van die hoop wat in ons lewe. Die aanvanklike verkondiging van die evangelie sal sekerlik meer duidelikheid vra. In die missionale gebruik van die teks word die verkondiging egter afhanklik gemaak van die navraag. Eers barmhartigheid en indien daar dan 'n navraag is, 'n geleentheid vir verkondiging. Maar wat as daar geen navraag is nie? Daar is geen chronologiese orde (van diens na navraag na verkondiging) wat deur 1 Petrus 3:15 gesuggereer word nie.

\section{Belydenisskrifte en Skrif}

Die gereformeerde teologiese vertrekpunt vir die hantering van die belydenisskrifte is die quia-standpunt. Die quatenusstandpunt is nog altyd verwerp. Blykbaar het die invloed van tekskritiek daartoe gelei dat Skrifverwysings in die belydenisskrifte problematies vir kritiese wetenskaplikes geword het. Die motivering is blykbaar dat die tekste wat gebruik word, wederregtelik as motivering vir leerstellings van die belydenisskrifte dien. Daar is dan ook versoeke dat die belydenisskrifte laat vaar moet word. My pogings om vas te stel watter tekste na bewering wederregtelik in die belydenisskrifte gebruik word, het tot dusver op niks uitgeloop nie. Een predikant wat die bewerings in 'n kerklike vergadering gemaak het, is herhaaldelik gevra om die betrokke tekste te identifiseer. Hy het egter tot vandag toe in gebreke gebly om die tekste te noem. Dergelike ongemotiveerde aanvalle op die tekste van die Skrif en Belydenisskrifte doen geweldig skade aan die geloofwaardigheid van die Bybel.

\section{Gevolgtrekking}

Die Bybel as Woord van God en die Christelike Kerk is wêreldwyd en in Suid-Afrika onder groot druk. Die gegewens wat in hierdie navorsing aangebied word, kan vergelyk word met die spreekwoordelike seekoei se oor. Die werklike ontstellende nuus is dat ons voortgaan asof alles nog in orde is. 'n Dokumentêre rolprent (\#christiannews 2020) oor die stand van die Christendom wat tans vertoon word, gee skokkende voorbeelde van belangrike katedrale en aanbiddingsplekke in Europa wat ontruim is en deur sekulêre bedrywighede in gebruik geneem is. Die gevolgtrekking wat gemaak word, is duidelik: die Christendom en Kerk in Europa het uitgesterf. In die gereformeerde konteks het duisende lidmate hulle na charismatiese gemeentes gewend om die stryd en onsekerheid in gereformeerde kerke te ontkom. Hoewel baie faktore daarvoor verantwoordelik is - sommige waarvan in hierdie navorsing bespreek is - moet die primêre rede vir die verval, die aanval op die Bybel as die Woord van God wees. Is dit betekenisvol dat die nuwe woord-virwoord vertaling van die Bybel verskyn juis in 'n tyd waarin die postmoderne uitstel van die woordbetekenis die lees van die Skrif relativeer? Is die oogmerk van die woord-virwoord vertaling om so na as moontlik aan die teks te bly? Waarom word gelowiges wat so na as moontlik aan die betekenis van die woord in die teks wil bly, dan fundamentaliste genoem? Daar was' $n$ tyd in die geskiedenis van Israel waarin die Wetboek van Moses (Woord) in onbruik geraak en tot vergetelheid gereduseer is (Neh 8). Is ons in Suid-Afrika daarheen op pad?

\section{Erkenning Mededingende belange}

Die outeur verklaar dat daar geen finansiële of persoonlike verbintenis is met enige party wat hom nadelig kon beïnvloed in die skryf van hierdie artikel nie.

\section{Outersbydrae}

J.v.R is die enigste outeur betrokke by die skryf van die artikel.

\section{Etiese oorwegings}

Hierdie artikel volg alle etiese standaarde vir navorsing.

\section{Befondsing}

Hierdie navorsing het geen spesifieke toekenning ontvang van enige befondsingsagentskap in die openbare, kommersiële of nie-winsgewende sektore.

\section{Data beskikbaarheid}

Die outeurs bevestig dat die data wat die bevindinge van hierdie studie ondersteun, beskikbaar is in die artikel.

\section{Vrywaring}

Die sienings en menings wat in hierdie artikel uitgedruk word, is dié van die outeur en weerspieël nie noodwendig die amptelike beleid of posisie van enige geaffilieerde verwantskap van die outeur nie.

\section{Literatuurverwysings}

\#christiannews, 2020, Europe leaves Christianity for 'Paganism', viewed 01 October 2020, from https://youtu.be/Otn3DzB2VNQ.

Algemene Sinode, 2019, 'Besluit oor selfdegeslagverhoudings', Konsepdokument vir bespreking deur ASDM, Maart 2020, Opgestel deur die AS span vir gesprek met sinodes oor die 2019-besluit.

Bell, R., 2011, Love wins: A book about heaven, hell, and the fate of every person who ever lived, Harper-Collins, New York, NY.

Bultmann, R., 2007, Theology of the New Testament, Baylor University Press, Waco, TX.

Castle, B., 2018, 'Analogical day view: Exegetical and systematic critique', Puritan Reformed Journal 10(2), 16-30.

Cilliers, S., 2020, 'NG Kerk se bekgeveg kring uit', Netwerk 24, 16 February, besigtig 01 Oktober 2020, vanaf https://www.netwerk24.com/Nuus/Algemeen/goudlandsinode-se-besluit-is-kinderagtig-ontstellend-20200216.

De Bruijne, A.D., 2016, 'Seksualiteit en cultuurstrijd: Een theologische voorstel tot dialog', Religie en Samenleving 11(2), 271-287. 
Degenaar, J., 1996, 'God, seks en politiek', in C.W. du Toit (red.), New modes of thinking on the eve of a new century, pp. 5-21, University of South Africa, Pretoria.

Degenaar, J., 2016. 'The collapse of dialog ["Sexuality and cultural conflict: A theological proposal for dialogue"]', Religie en Samenleving 11(2), 271-287.

Fergusson, D., 2013, 'The Bible in modernity', in A. Paddison \& N. Messer (eds.), The Bible: Culture, community, society, pp. 123-136, Bloomsbury, London.

Flax, J., 1990, Thinking fragments: Psychoanalysis, feminism, and postmodernism in the contemporary West, University of California Press, Berkeley, CA.

Graham-Dixon, A., 2017, Artists: Their lives and works, Penguin Random House, London.

Greidanus, S., 1999, Preaching Christ from the Old Testament, WB Eerdmans, Grand Rapids, MI.

Heelan, P.A., 1985, 'Perception as a hermeneutic act', in H.J. Silverman \& S. Ihde (eds.), Hermeneutics and deconstruction, pp. 50-55, State University of New York Press, Albany, NY.

Heidegger, M., 1962, Being and time, transl. J. Macquarrie \& E. Robinson, Blackwell, Oxford.

Heyns, J.A., 1967, Denkers deur die eeue, Tafelberg Uitgewers, Kaapstad.

Janse van Rensburg, J., 1979, 'Die herwaardering van revolusie in die modern teologiese sosiale etiek: 'n Kritiese studie', PhD-proefskrif, Universiteit Stellenbosch, Stellenbosch.

Janse van Rensburg, J., 1999, The occult debate, Lux Verbi, Cape Town.

Janse van Rensburg, J., 2000, The paradigm shift, Van Schaik, Pretoria.

Janse van Rensburg, J., 2010, 'A qualitative investigation into the so-called ministry of deliverance', In die Skriflig 44(3\&4), a167. https://doi.org/10.4102/ids. $\mathrm{v} 44 \mathrm{i} 3 / 4.167$

Janse van Rensburg, J., 2011, Jesus is die Een! Christelike Media Publikasies, Kaapstad.

Janse van Rensburg, J., 2012, 'Responsible preaching from the Old Testament', in H. Kruger, E. Orsmond \& H. van Deventer (eds.), Perspectives on mission in the Old Testament, pp. 25-26, Christian Literature Fund, Wellington.

Jones, A., 2005, Reimagining Christianity. Reconnenct your spirit without disconnecting your mind, John Wiley \& Sons, Hoboken, NY.

Jonker, W.D., 1976, Die Woord as opdrag, NG Kerkboekhandel, Pretoria.

Joubert, S., 2009, Jesus - 'n Radikale sprong, CUM, Vereeniging.

Kant, I., 1977, The Critique of Practical Reason, viewed 01 October 2020, from https:// www.gutenberg.org/files/5683/5683-h/5683-h.htm.

König, A., 2009, Die evangelie is op die spel, Lux Verbi BM., Wellington.

Krige, M., 2020, 'Wat in profesieë staan is bloot nie waar nie', Volksblad, 05 Augustus, besigtig 1 Oktober 2020, vanaf https://www.netwerk24.com/Stemme/MyStem/ wat-in-profesiee-staan-is-bloot-nie-waar-nie-20200804.

Loevlie, L., 1992, 'Postmodernism and subjectivity', in S. Kvale (ed.), Psychology and postmodernism, pp. 88-105, Sage, London.

Louw, J., 2020, Reaksie op ASMJ se gids oor homoseksualiteit, besigtig 01 Oktober 2020 vanaf http://www.glodiebybel.co.za/reaksie-op-asm-se-gids-oor-homoseksualiteit/.

Lyotard, J.-F., 1984, The postmodern condition, University of Minnesota Press, Minneapolis, MN.

Martoia, R., 2007, 'Sweefstokleierskap', in S. Joubert (red.), Die perfekte storm, p. 109, CUM, Vereeniging.

Mcknight, S., 2004, 'Jesus of Nazareth', in S. McKnight \& G.R. Osborne (eds.), The face of New Testament studies, Baker Academic, Ada, Ml.
Mcknight, S. \& Osborne, M.G.R. (ed.), 2004, The face of New Testament Studies. A survey of recent research, Baker Academic, Ada, MI.

Mclaren, B.D., 2006, The secret message of Jesus, W. Publishing Group, HarperCollins, Nashville, TN.

Mulder, F., 2011, Opgestaan: Studente se stryd om geloof by Tukkies in die jare 2001-2006, Opgestaan Publikasies, Cambridge.

Mulder, F., 2020, Confessional seminary takeovers, viewed 1 October 2020, from https://m.youtube.com/watch?v=8vOixn4C3WQ\&fbclid=IwAR1gdFMjIVvJRa09a AJt3HnnirO-neDeROypjKWBuTX5sevJPL_hPYpgmZ8.

Müller, J., 2006, Opstanding, Lux Verbi, Wellington.

Müller, J., 2010, 'Dit wat ons nié dink nie', besigtig 01 Oktober 2020, vanaf https:// www.glodiebybel.co.za/dit-wat-ons-nie-dink-julian-muller/.

Nauta, D., 1963, Geschiedenis van de Kerk, deel 1, J.H. Kok, Kampen.

Niemandt, N., 2007, Nuwe drome vir nuwe werklikhede, Lux Verbi, Wellington.

Niemandt, N., 2012, 'Nuwe bedeling en nuwe lewe', Beeld, 15 April, besigti 01 Oktober 2020, vanaf https://www.glodiebybel.co.za/nuwe-bedeling-ennuwe-lewe-2012-04-16/.

Ouweneel, W.J., 1978, Het domein van de slang: Christelijke handbook over occultisme en mysticism, Buijten \& Schipperheijn BV Drukkerij, Amsterdam.

Pienaar, A., 2010, 'In ons koppe en harte gebeur God', Sentrum vir eietydse Spiritualiteit, besigtig 01 Oktober 2020, vanaf https://www.spiritualiteit.co.za/ artikel-in-ons-koppe-en-harte-gebeur-god.php.

Pieterse, H.J.C., 2020, 'The Grounded Theory methodology to conduct content analysis of sermons and interviews: Critique and response', HTS Teologiese Studies 76(1), 1-5. https://doi.org/10.4102/hts.v76i1.5851

Pippen, R.B., 1991, Modernism as a philosophical problem: On the dissatisfactions of European high culture, Blackwell, Cambridge.

Schrag, C.O., 1985, 'Subjectivity and praxis at the end of philosophy', in S. Silverman \& D. Ihde (eds.), Hermeneutics in deconstruction, p. 24, University of New York Press, New York, NY

Seidman, S., 1994, Contested knowledge: Social theory in the postmodern era, Oxfords, Blackwell.

Speckman, M., 2016, 'Bible subversion: An ideology critique of the manner and motif behind the use of scripture by politicians', HTS Teologiese Studies 72(1), 1-9. https://doi.org/10.4102/hts.v72i1.3185

Strauss, D.F.M., 1998, 'Die postmodernisme - Metodologiese oorweging', Tydskrif vir Christelike Wetenskap 34, April, 13-33.

Strauss, P.J., 2018, 'Johan Heyns and critique in the Dutch Reformed Church against apartheid: The moderator a prophet?', HTS Teologiese Studies 74(3), 1-8. https://doi.org/10.4102/hts.v74i3.4965

Sweet, L., 1991, Quantum spirituality, Whaleprints, Dayton, $\mathrm{OH}$

Tutu, D., 2011, God is not a Christian: And other provocations, HarperOne, San Francisco, CA.

Ulmer, G., 1983, 'On writing: Derrida's solicitation of theoria', in M. Krupnick (ed.) Displacement: Derrida and after, p. 31, Indiana University Press, Bloomington, IN.

Van Aarde, A., 2001, Fatherless in Galilee: Jesus as child of God, Trinity Press International, Harrisburg, PA.

Wisse, M., 2002, 'From cover to cover? A critique of Wolterstorff's theory of the Bible as divine discourse', International Journal for Philosophy of Religion 52, 159-173. https://doi.org/10.1023/A:1020899513041

Wolf, E., 1975, Sozialethik: Theologische Grundvragen, Vandenhoeck \& Ruprecht, Götingen Wolfe, J., 2014, Heidegger and theology, Bloomsbury, London. 